\title{
EJMSS
}

Eurasian Journal of Management \& Social Sciences

\section{Transformational Leadership Impact on Employees Performance}

\author{
Cemil Top ${ }^{1} \&$ Bryar Mohammad Sharif Abdullah ${ }^{2}$ \& Akar Hemn Mahmood Faraj ${ }^{3}$ \\ ${ }^{1}$ Department of Business and Management, Faculty of Administrative Sciences and \\ Economics, Tishk International University Erbil, Iraq \\ ${ }^{2,3}$ Independent Researcher, Sulaymaniyah, Iraq \\ Correspondence: Cemil Top, Tishk International University, Erbil, Iraq. \\ Email: cemil.top@tiu.edu.iq
}

Doi: 10.23918/ejmss.v1i1p49

\begin{abstract}
The aim of the paper is to investigate transformational leadership effects on employee performance in the Kurdistan region of Iraq. To do this, 252 data were collected from Erbil and Sulaymaniyah cities of Kurdistan. Results of the study revealed that transformational leaders positively related with employee performance. Further, inspirational motivation and individual consideration have significant impact on employee performance. It is suggested that managers in the region should motivate and individually care with their employees to increase their performance.
\end{abstract}

Keywords: Transformational Leadership, Employee Performance, Kurdistan Region of Iraq

\section{Introduction}

The world is witnessing radical transformations in dealing with the data and concept of management and economy. Particularly, in relation to the management of resources and capital, which results in greater complexity of the challenges is directed by human day after day, especially in light of technological progress and the information revolution (Budur, 2018b; Budur et al., 2018). Further, in light of the growing complex environment of economic and social systems, especially in terms of the different use economic resources (Demir, 2019; Torlak et al., 2019), most of the leaders and businessmen who are interested in developing their firms keep abreast of global changes in management strategies and stystems (Budur et al., 2019). 
In this concept, leadership is the mechanism of supporting or motivating a group of people to work towards achieving a common goal, where it can be leading employees and workers with a strategy to achieve a vision (Tajeddini, 2015). Besides, a leader has different actions such as a clear vision about future, specific and clear objectives that encourages subordinates to set their goals and long-term vision. In this regard, leadership is the process of inspiration others especially influence the workers with the aim of raising their abilities for organizational success (Demir et al., 2019; Torlak \& Kuzey, 2019; Ali et al., 2020; Mohammed et al., 2020).

Further, transformational leadership is one of the styles of leadership in which the leader identifies the needs for change, creates a vision to guide the change through inspiration, and positive conduct for increased commitment of the members in the organization (Burns, 1978; Yukl, 1999). The theory of transformational leadership has also witnessed a remarkable development during the contributions of Bass (1985) in a systematic theory, where he developed models and measures for these methodologies. Additionally, transformationalism was represented in charisma, creative encouragement and attention to the individual (Bass \& Avolio, 1994).

Furthermore, transformational leadership has strong positive effects on employee outcomes (MacKenzi et al., 2001). Scholars noted that these leaders are positively related to employee performance, employee commitment, satisfaction, individual and group performance, organizational effectiveness and employee customer orientation (Budur \& Demir, 2019ab). Furthermore, transformational leaders promote confidence in the workplace and share authority in making different decisions (Madhu, \& Krishnan, 2005). They represent democratic style of leadership that employee has to some extent discretionary power to do work, so their performance is better than in autocratic style (McCleskey, 2014).

On the other hand, unfortunately, we still find many leaders struggling to survive with traditional leadership methods where they are still characterized by individualistic orientation that avoids teamwork in Kurdistan (Khan \& Yildiz, 2020). It is observed that overall vision and lack of administrative clarity hangs over the atmosphere of senior management in the region (Altun, 2019). Besides, managerial reactions and attitudes for dealing with events are far away from the effectiveness and creativity for the success of the company. So far, the current study carries out the necessary analyzes that allow to highlight 
the importance of the link between administrative leadership and the performance of employees in the organization.

\section{Literature Review}

\subsection{Transformational Leadership}

Leadership is a broadly discussed topic in the literature. Its antecedents and consequences have greater impact on organizational outcomes and performance. Scholars, such as (Hater \& Bass, 1988; Den Hartog \& Belschak, 2012) contributed in the literature as describing the prominent styles of transactional and transformational leaderships. Transactional leadership is defined as the exchange of rewards and objectives between employees and managers (Howell \& Avolio, 1993). Further, transactional leaders motivate employees with rewards to fulfill requirements (Bass, 1990; Humphreys, 2002; Tajeddini, 2016). Besides, transformational leadership focuses on the development of followers and their needs. Managers exercising transformational leadership style for the development of value system of employees, namely motivation and moral (Ismail et al., 2012). Additionally, transformational leaders act as a bridge between leaders and followers to develop clear understanding of follower's interests, values and motivations (Bass, 1994; Bycio et al., 1995; Tajeddini et al., 2017).

Bushra et al., (2011) noted that there is a positive relationship between transformational leadership and both job satisfaction and job commitment of employees in bank sector. Beside they asserted that transformational leaders help workers to become more creative and innovative to adapt the external environment. Additionally, Haider and Riaz, (2010) suggested that transformational leaders play a crucial role in the quality performance for the organization. Besides, this study revealed a strong link between leadership and career developments. Consequently, Gumusluoglu and lisev, (2008) showed that transformational leadership has significant impact on organizational innovation during market trends, especially in new industries.

\subsection{Employee Performance}

Employee performance is employees' outcomes that meet the requirements. Further, employee performance could be understood in compare to coworkers' fulfilments in the workplace (Buil et al., 2019). Furthermore, scholars defined employee performance in two 


\section{EJMSS Eurasian Journal of Management \& Social Sciences}

ways, which are in-role and extra role performance. Meeting requirements is in-role performance while helping others or acting beyond expectations are extra role behaviors of the employees (Dinc \& Aydemir, 2014).

\subsection{Hypotheses}

According to literature of the study, it is proposed that transformational leaders have positive impacts on the employee performance in the organizations. Many scholars noted that dimensions of these leaders have significant relationship with employee performance. Therefore, current study has conceptualized the following hypotheses (Figure, 1).

Transformational Leadership

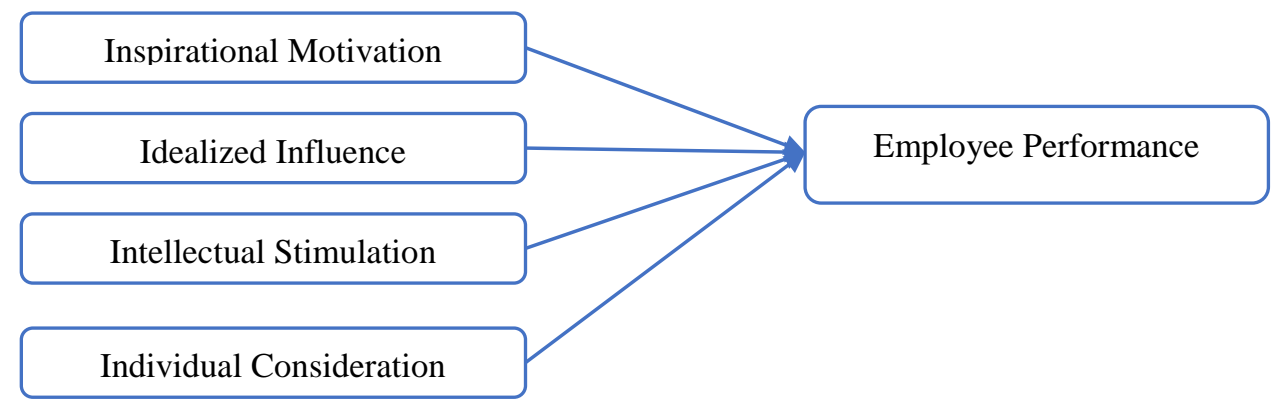

Figure 1: Model of the Study

H1: Idealized influence has positive impact on Employee performance

$\mathrm{H} 2$ : Inspirational motivation has positive impact on Employee performance

H3: Intellectual stimulation has positive impact on Employee performance

H4: Individual consideration has positive impact on Employee performance

\section{Methodology}

The aim of the study was to identify the impact of transformational leadership effects on employee's performance in Kurdistan region. To do this, a survey questionnaire has been 


\section{EJMSS Eurasian Journal of Management \& Social Sciences}

proposed and applied in Erbil and Sulaymaniyah cities of Kurdistan. 252 data were collected from the managers and employees of the shopping malls in the region and evaluated for further analyses of the study.

\subsection{Sampling}

In data collection, various forms were given to the participants of both sales staff and directors to fill them out and represent their feedback on leadership impacts on employee's performance. Questions of the survey have been adapted from Bass (1985) and Budur and Demir (2019) studies. The questions have been answered according to 5-point Likert scale, where 1 strongly disagree and 5 strongly agree choices. It is worthy to mention that data collection was not that easy to get in Erbil as people were not ready and responsive to fill out the survey. Also, in Sulaymaniyah we faced difficulties to apply the survey.

\subsection{Results}

\subsubsection{Demography}

The demographic questions include the level of education. So far, the result showed that the first group consisted of 58 persons which was $\% 23$ of respondents were (High school) graduated and the second group 62 persons with $\% 24$ percent were from (Vocational school) and the third group where $\% 51$ of participants had university level education which is the highest level with 130 people and the last one was master degree holder that is represented with just 2 persons that occupies $\% 0.7$.

Table 1: Education level of the respondents

\begin{tabular}{|l|c|c|}
\hline Education & Percentage & Frequency \\
\hline Master and Ph.D. & $0.7 \%$ & 2 \\
\hline University & $51.6 \%$ & 130 \\
\hline Vocational school & $24.6 \%$ & 62 \\
\hline High school & $23.0 \%$ & 58 \\
\hline Total & $100.0 \%$ & 252 \\
\hline
\end{tabular}




\section{EJMSS Eurasian Journal of Management \& Social Sciences}

The second part of the demographic questions was the experience of the respondents. Less than one year is represented with \% 23.5 which is 59 people. That means HR managers in Kurdistan give duties to peoples or employees that do not have enough experiences and provide them chance to learn and fulfill requirements. Second group of employees have experiences between 1-5 years with 140 employees and occupies \%55.5. The third group were 6-10 years' experiences and is represented with \%13 of 33 employees. Finally, the other group that contains 11 people with $\% 7.8$ of the employees is the ones with more than 15 years of experiences.

Table 2: Experience of the Respondents

\begin{tabular}{|l|c|c|}
\hline Experience in Industry & Percentage & Frequency \\
\hline More than 15 years & $4.3 \%$ & 11 \\
\hline $11-15$ year & $3.5 \%$ & 9 \\
\hline $6-10$ year & $13.1 \%$ & 33 \\
\hline $1-5$ year & $55.5 \%$ & 140 \\
\hline Less than one year & $23.5 \%$ & 59 \\
\hline
\end{tabular}

Every business should have authority among the staff to increase the effectiveness of the management based on their skills. According to our survey most of the participants were from non-managerial position which consists of \%71 (180 employees) and the top managerial level with \% 15 respectively, and the low-level management and middle management take place in this survey $\% 7.5$ and $\% 5.5$ jointly. They indicate that normal employees have more time and less responsibility to participate in this kind of activities and answering surveys.

Table 3: Positions of the respondents

\begin{tabular}{|l|c|c|}
\hline Position & Percentage & Frequency \\
\hline Non-managerial employee (expert) & $71.4 \%$ & 180 \\
\hline Low-level management & $7.5 \%$ & 19 \\
\hline Middle management & $5.5 \%$ & 24 \\
\hline Top management & $15.5 \%$ & 39 \\
\hline Total & & 252 \\
\hline
\end{tabular}




\section{EJMSS Eurasian Journal of Management \& Social Sciences}

The gender distribution of the study revealed that majority of the employees were represented as male with \% 55 that consisted of 139 people and female workers were $\% 44$ that was 113 people jointly.

Table 4: Gender of the participants

\begin{tabular}{|l|c|c|}
\hline Gender & Percentage & Frequency \\
\hline Female & $44.9 \%$ & 113 \\
\hline Male & $55.1 \%$ & 139 \\
\hline
\end{tabular}

The Table below gives the information about the results of the analyses between independent variables which are (idealized influence, inspirational motivation, intellectual stimulation and individual consideration) and dependent variable which is employee performance. In basic words, both the terms measure the relationship and the reliance between two factors. "Covariance" demonstrates the course of the straight connection between factors. "Correlation" measures both the quality and course of the straight relationship between two factors. Correlation is a component of the covariance. So far, while correlation esteems are institutionalized; covariance esteems are most certainly not.

Table 5: Results of the Analyses

\begin{tabular}{|l|l|c|c|c|c|c|}
\hline $\begin{array}{l}\text { Independent } \\
\text { Variables }\end{array}$ & $\begin{array}{l}\text { Dependent } \\
\text { Variable }\end{array}$ & Correlation & Covariance & $\begin{array}{l}\text { Adjusted } \\
\text { R Square }\end{array}$ & t Stat & $\begin{array}{c}\mathrm{R} \\
\text { Square }\end{array}$ \\
\hline $\begin{array}{l}\text { Idealized } \\
\text { Influenced }\end{array}$ & $\begin{array}{l}\text { Employee } \\
\text { Performance }\end{array}$ & 0.0666 & 0.0250 & 0.002 & 5.539 & 0.004 \\
\hline $\begin{array}{l}\text { Intellectual } \\
\text { Stimulation }\end{array}$ & $\begin{array}{l}\text { Employee } \\
\text { Performance }\end{array}$ & 0.1309 & 0.0444 & 0.019 & 7.195 & 0.015 \\
\hline $\begin{array}{l}\text { Individual } \\
\text { Consideration }\end{array}$ & $\begin{array}{l}\text { Employee } \\
\text { Performance }\end{array}$ & 0.1683 & 0.0638 & 0.015 & 10.49 & 0.021 \\
\hline $\begin{array}{l}\text { Inspirational } \\
\text { Motivation }\end{array}$ & $\begin{array}{l}\text { Employee } \\
\text { Performance }\end{array}$ & 0.2323 & 0.0743 & 0.047 & 10.74 & 0.054 \\
\hline
\end{tabular}




\section{EJMSS}

Eurasian Journal of Management \& Social Sciences

According to covariance and correlation results, inspirational motivation is the strongest factor on the employee performance. Then it is followed by individual consideration. Further, based on the t-statistic values where all are stronger than 1.96 show that the proposed hypotheses are accepted. Finally, idealized influence and intellectual stimulation showed weak impact on employee performance respectively. Consequently, H1, H2, H3, and $\mathrm{H} 4$ have been accepted.

\section{Conclusion}

The aim of the study was to investigate transformational leadership effects on the employee performance in the Kurdistan region of Iraq. To do this, we have visited some companies in Erbil and Sulaymaniyah city of Kurdistan. According to our study we have found that the transformational leadership has significant impacts on employee performance. Especially, inspirational motivation of transformational leaders have positive impacts on employees' performance in the region. Therefore, it is suggested that managers of the companies should construct positive communication and relationships with employees and try to motivate them about the objectives of the companies. Secondly, individual consideration dimension of transformational leadership has positive correlation on employees' performance. Therefore, it is suggested to residential managers to encourage employees individually to follow their job requirements. Besides, managers should care about employees' problems and needs in the workplace and provide them related trainings to increase their performance.

\section{References}

Ali, S. H. K., Khan, N. S., \& Yildiz, Y. (2020). Leadership effects on CSR employee, media, customer, and NGOs. Management and Eco-nomics Research Journal, $6,1-9$.

Altun, M. (2019). The Effect of Extra-Curricular Activities in Hizmet Movement Schools on Students' Personal Growth: A Case Study in Kurdistan Region, Iraq. International Journal of Academic Research in Business and Social Sciences, 9(2), 203-210.

Bass, B. M. (1985). Leadership and performance beyond expectations. New York, Free Press.

Bass, B. M., \& Avolio, B. J. (1994). Transformational leadership and organizational culture. The International Journal of Public Administration, 17(3-4), 541-554. 
Budur, T. (2018a). Analytic Hierarchy Process to Evaluate Corporate Image, Trust, and Switching Cost of GSM Operators: A Case of Kurdistan Region of Iraq. International Journal of Social Sciences \& Educational Studies, 5(2), 241-250

Budur, T. (2018b). The impact of Al-Ghazali's virtues on organizational commitment and performance: A case Study at private education institutions in Kurdistan Region of Iraq. Icabep, Erbil-Iraq, 2, p21.

Budur, T., \& Demir, A. (2019a). Leadership Effects on Employee Perception about CSR in Kurdistan Region of Iraq. International Journal of Social Sciences \& Educational Studies, 6(1), 142-154.

Budur, T., \& Demir, A. (2019b). Leadership Perceptions Based on Gender, Experience, and Education Leadership Perceptions Based on Gender, Experience, and Education. International Journal of Social Sciences \& Educational Studies, 6(1), 142-154.

Budur, T., Faraj, K. M., \& Karim, L. A. (2019). Benchmarking operations strategies via hybrid model : A case study of café-restaurant sector. Amazonia Investiga, 8(23), 842-854.

Budur, T., Rashid, C. A., \& Poturak, M. (2018). Students Perceptions on University Selection, Decision Making Process: A Case Study in Kurdistan Region of Iraq. International Journal of Social Sciences \& Educational Studies, 5(1), 133-144.

Buil, I., Martínez, E., \& Matute, J. (2019). Transformational leadership and employee performance: The role of identification, engagement and proactive personality. International Journal of Hospitality Management, 77, 64-75.

Burns, J. (1978). Leadership. New York, NY: Harper \& Row.

Bushra, F., Ahmad, U., \& Naveed, A. (2011). Effect of transformational leadership on employees' job satisfaction and organizational commitment in banking sector of Lahore (Pakistan). International Journal of Business and Social Science, 2(18), 261-267.

Bycio, P., Hackett, R. D., \& Allen, J. S. (1995). Further assessments of Bass's (1985) conceptualization of transactional and transformational leadership. Journal of Applied Psychology, 80(4), 468.

Demir, A., Shawkat, S., Majeed, B.N., Budur, T. (2019). Fuzzy AHP and VIKOR to select best location for bank investment: Case study in Kurdistan Region of Iraq. In Effective investments on capital markets, Tarczyn'sk W, Nermend K (eds). Springer: Cham; 485-510.

Demir, A. (2019). A benchmarking of service quality in telecommunication services: Case study in Kurdistan Region of Iraq. International Journal of Social Sciences \& Educational Studies, 5(3), 216-231. 
Demir, A., \& Budur, T. (2019). Roles of leadership styles in corporate social responsibility to non-governmental organizations (NGOs). International Journal of Social Sciences \& Educational Studies, 5(4), 174-183.

Den Hartog, D. N., \& Belschak, F. D. (2012). When does transformational leadership enhance employee proactive behavior? The role of autonomy and role breadth self-efficacy. Journal of Applied Psychology, 97(1), 194.

Dinc, M. S., \& Aydemir, M. (2014). Ethical leadership and employee behaviours: an empirical study of mediating factors. International Journal of Business Governance and Ethics, 9(3), 293-312.

Gumusluoglu, L., \& Ilsev, A. (2008). Transformational leadership, creativity, and organizational innovation. Journal of Business Research, 62(4), 461-473.

Hater, J. J., \& Bass, B. M. (1988). Superiors' evaluations and subordinates' perceptions of transformational and transactional leadership. Journal of Applied Psychology, 73(4), 695.

Howell, J. M., \& Avolio, B. J. (1993). Transformational leadership, transactional leadership, locus of control, and support for innovation: Key predictors of consolidated-business-unit performance. Journal of Applied Psychology, 78(6), 891.

Humphreys, J. H. (2002). The Anabasis and lessons in leadership: Xenophon as a prototypical transformational leader. Journal of Management Research, 2(3), 136-146.

Ismail, A. M., Reza, R., \& Mahdi, S. (2012). Analysis the relationship between cultural intelligence and transformational leadership. International Journal of Business and Social Science, 3(14), 252-261.

Khan, N. U. S., \& Yildiz, Y. (2020). Impact of Intangible Characteristics of Universities on Student Satisfaction. Amazonia Investiga, 9(26), 105-116.

MacKenzie, S. B., Podsakoff, P. M., \& Rich, G. A. (2001). Transformational and transactional leadership and salesperson performance. Journal of the Academy of Marketing Science, 29(2), 115.

Madhu, B., \& Krishnan, V. R. (2005). Impact of transformational leadership and karmayoga on organizational citizenship behavior. Prestige Journal of Management and Research, 9(1), 1-20.

McCleskey, J. A. (2014). Situational, transformational, and transactional leadership and leadership development. Journal of Business Studies Quarterly, 5(4), 117.

Mohammed, S. S., Suleyman, C., \& Taylan, B. (2020). Burnout determinants and consequences among university lecturers. Amazonia Investiga, 9(27), 13-24.

Tajeddini, K. (2015). Using the integration of disparate antecedents to drive world-class innovation performance: An empirical investigation of Swiss watch 


\section{EJMSS Eurasian Journal of Management \& Social Sciences}

manufacturing firms, tékhne. Review of Applied Management Studies, 13(1), $34-50$.

Tajeddini, K. (2016). Analyzing the influence of learning orientation and innovativeness on performance of public organizations: The case of Iran, Journal of Management Development, 35(2), 134-153.

Tajeddini, K., Walle, A.H., \& Denisa, M., (2017). Enterprising women, tourism, and development: The case of Bail. International Journal of Hospitality \& Tourism Administration, 18(2), 195-218.

Torlak, N. G., \& Kuzey, C. (2019). Leadership, job satisfaction and performance links in private education institutes of Pakistan. International Journal of Productivity and Performance Management, 68 (2), 276-295. https://doi.org/10.1108/IJPPM-05-2018-0182

Torlak, N. G., Demir, A., \& Budur, T. (2019). Impact of operations management strategies on customer satisfaction and behavioral intentions at caférestaurants. International Journal of Productivity and Performance Management. https://doi.org/10.1108/IJPPM-01-2019-0001

Yildiz, Y., \& Budur, T. (2019). Introducing Environmental Awareness to College Students with Curricular and Extracurricular Activities. International Journal of Academic Research in Business and Social Sciences, 9(3), 666-673.

Yukl, G. (1999). An evaluation of conceptual weaknesses in transformational and charismatic leadership theories. Leadership Quarterly, 10(2), 285-305. https://doi.org/10.1016/S1048-9843(99)00013-2 